\title{
New Fannia Robineau-Desvoidy from Amazonas, Brazil and new geographical record (Diptera, Fanniidae)
}

\author{
Márcia S. Couri ${ }^{1,2} \&$ Erika Winagraski ${ }^{1}$ \\ ${ }^{1}$ Departamento de Entomologia, Museu Nacional, Quinta da Boa Vista, 20940-040 Rio de Janeiro, Rio de Janeiro, Brasil. \\ E-mail: mcouri@attglobal.net \\ ${ }^{2}$ Research fellow of CNPq.
}

\begin{abstract}
Fannia Robineau-Desvoidy, 1830 is known from 68 Neotropical species, two of them occuring in the Amazon State (Brazil). The analysis of a material recently collected in Pico Tamacuari, Amazonas, led to the description of F. caramaschi sp. nov., herein described with illustrations from male and female. F. obscurinervis Stein, 1900 is recorded for this State for the first time. A key to the identification of the four Fannia species recorded to Amazon is also presented.

KEY WORDS. Description, Fannia caramaschi, new species, Pico Tamacuari, taxonomy.

RESUMO. Nova Fannia Robineau-Desvoidy do Amazonas, Brasil e novo registro geográfico (Diptera, Fanniidae). Fannia Robineau-Desvoidy, 1830 é conhecida por 68 espécies neotropicais, duas delas com ocorrência no Estado do Amazonas (Brasil). A análise de um material recentemente coletado no Pico Tamacuari, Amazonas levou a descrição de F. caramaschi sp. nov., aqui descrita, com ilustrações, do macho e da fêmea. F. obscurinervis Stein, 1900 é registrada pela primeira vez para este Estado. Uma chave para identificação das quatro espécies de Fannia assinaladas para a Amazônia também é apresentada.

PALAVRAS CHAVE. Descrição, Fannia caramaschi, nova espécie, Pico Tamacuari, taxonomia.
\end{abstract}

From the 68 Fannia Robineau-Desvoidy described to the neotropical region, only two are recorded to the Amazon State (Brazil) - F. trimaculatoides Couri and Pamplona, 1991 and F. rafaeli Carvalho \& Couri, 1993 (CARvalHo et al. 2003, Couri in press).

The analysis of a material recently collected in Pico Tamacuari, Amazonas, led to the description of a new Fannia species and a new geographical record for another Fannia species.

\section{MATERIAL AND METHODS}

The material was collected at the base camp in the southern slope of Pico Tamacuari $\left(1^{\circ} 12^{\prime} 26^{\prime \prime} \mathrm{N}, 64^{\circ} 47^{\prime} 18^{\prime \prime} \mathrm{W}, 350 \mathrm{~m}\right.$ above sea level), a component of the Serra do Tapirapecó. This mountain ridge forms part of the northwestern border of Brazil with the southeastern border of Venezuela, extending from southwest to northeast for a little over $100 \mathrm{~km}$, with a width of about $20 \mathrm{~km}$. The Pico Tamacuari rises above the rest of the chain, to an elevation of $2340 \mathrm{~m}$. For more details of the region, see Myers \& Donnelly (1997).

The base camp was established on the left margin of a small, unnamed river, in a primary, well preserved forest still poorly known botanically. The canopy of the forest rises about $20 \mathrm{~m}$ above ground and its interior is clean, with poorly developed subshrub and thin leaf litter. The region is included in the Yanomami indians territory, which are almost the only human inhabitants.
The dipteran specimens were traped in the tents constructed to serve as laboratories for herpetological and mastozoological studies. No bait was especifically used, but probaly the scent of blood from the collected specimens, preserving substances, and the sweat of the researchers were atractive to them.

The terminalia were prepared in a solution of potassium hydroxide at $10 \%$, in water-bath, for ten minutes, and dissected in glycerol. They were then placed in microtubes with glycerol and pinned together with the specimen.

All material is deposited at the collection of Museu Nacional, Rio de Janeiro.

Key to the males Fannia species recorded in the Amazon State, Brazil

1. Wings hyaline with no brown marks [Brazil (Amazonas)] . .F. trimaculatoides

1 '. Wings smoky or with brown clouds 2

2. Wings with dark brown clouds at costal and at r-m and dmcu cross veins [Mexico, Venezuela, Guyana, Colombia, Peru, Bolivia, Brazil, Paraguay] F. obscurinervis

2'. Wings brownish specially on superior longitudinal third, with no dark brown marks on cross veins (sometimes very faint)......

3. Mesonotum with grey pollinosity with two brown vittae at 


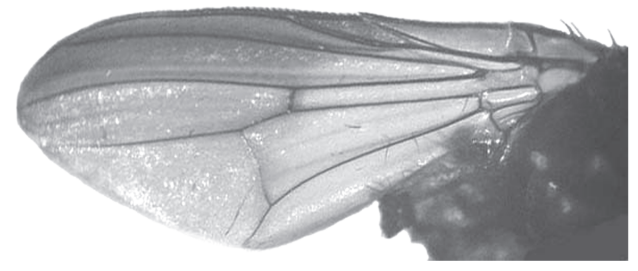

1

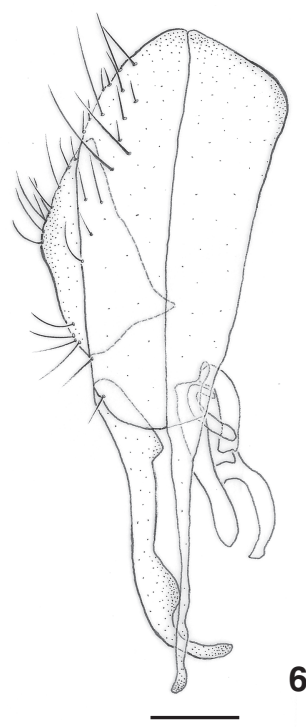

6

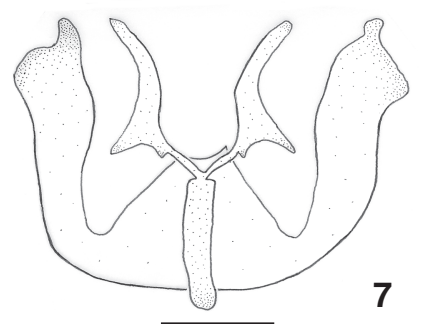

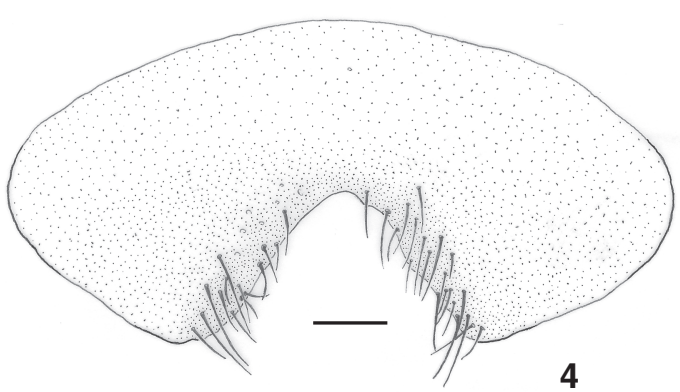

4

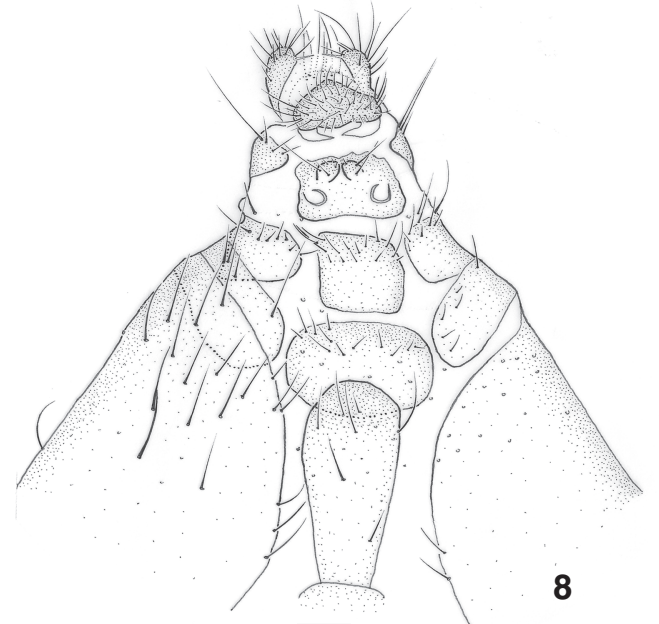

2

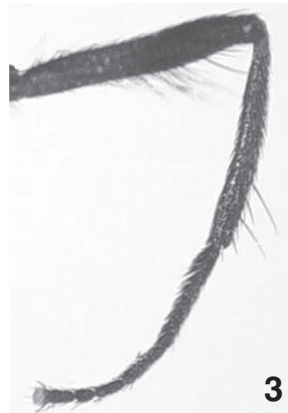

3
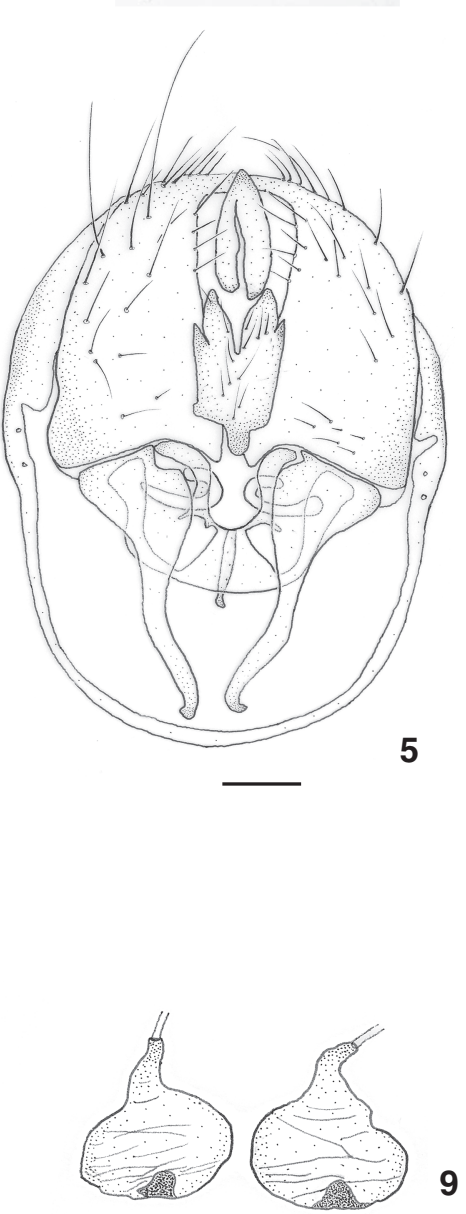

Figs 1-9. Fannia caramaschi sp. nov. (1-7) Male: (1) wing; (2) mid femur and tibia, anterior view; (3) hind femur and tibia, anterior view; (4) sternite 5; (5) cercal plate and surstyli, dorsal view; (6) cercal plate and surstyli, lateral view; (7) phallic complex, dorsal view; (8-9) female: (8) ovipositor, dorsal view; (9) spermathecae. Scales $=0.1 \mathrm{~mm}$.

dorsocentral surfaces; wing with a longitudinal faint mark at costal [Brazil (Amazonas)] F. rafaeli

3'. Mesonotum dark brown shiny, with no vittae; wing a longitudinal very dark mark at costal (Fig. 1) [Brazil (Amazonas)] F. caramaschi sp. nov.

\section{Fannia obscurinervis Stein, 1900}

Examined material. BraziL, Amazonas: Município de Barcelos (Pico Tamacuari, 2700 m, NW da Missão Marari, $1^{\circ} 12^{\prime} 26$, $4^{\prime \prime} \mathrm{N}$; $64^{\circ} 47^{\prime} 18,1^{\prime \prime}, 340 \mathrm{~m}$ de altitude); 5 males and 21 females, 29.IV-10.V.2004, U. Caramaschi leg. 
Comments. This species was previously recorded to Mexico, Venezuela, Guyana, Colombia, Peru, Bolivia, Paraguay and Brazil, but not to the Amazon State.

\section{Fannia caramaschi sp. nov.}

Figs $1-9$

Colour. General colour dark brown, a little shiny, with very few dark grey pollinosity. Apex of pedicel and flagellum brown with faint golden pollinosity. Arista dark brown, yellowish at the base. Palpus dark brown. Calipters hyaline, a little yellowish. Halter light brown, with dark brown knob. Wings infuscated with a longitudinal brown cloud on the superior third (Fig. 1), sometimes a very faint brown cloud at $r-m$ and dm-cu cross veins. Legs dark brown. Abdomen dark brown with very faint lateral grey pollinosity on tergites $1+2$ to 4 .

Male. Length: body: 6,1-6,9 mm; wing: 5,5-5,8 mm.

Head. Eyes bare, holoptic, anterointernal facets enlarged, interocular space a little larger than the diameter of the anterior ocellus. About 16 -18 pairs of frontal setae. Ocellar seta a little shorter than the frontals. Antena inserted below middle of eyes; flagellum about 1.5 longer than pedicel. Arista weakly pubescent. Vibrissa strong and little longer than the frontal setae.

Thorax. Acrostichal setulae in three disarranged rows, prescutelar pair well developed; dorsocentrals setae 1:3; 2 intraalars; 1 supra-alar; 1 post-alar. Scutellum with one pair of subapical and one pair of apical setae, both long; one sub-apical row of thin and short setae. Notopleuron with two long setae. Anepisternum with a row of about eight long setae. Proepimero with a long seta. Inferior calypter about 1.8 longer than the superior one. Legs: fore femur with a row of long posterodorsal and posteroventral bristles. Fore tibia with 1 short submedian anterodorsal seta, 1 long pre-apical dorsal and 1 pre-apical posteroventral. Mid femur with four rows of bristles: 1 anterodorsal, 1 posterior, 1 posteroventral and 1 anteroventral, all with longer setae at the apical third. Mid tibia with 1 submedian anterodorsal seta and 1 pre-apical; 1 submedian and 1 apical posterodorsal setae; 1 apical posteroventral and 1 apical anteroventral. Ventral surface with two concavities at the basal half (Fig. 2). Hind leg as in figure 3. Hind femur with a row of anterodorsal and posteroventral setae; anteroventral long setae at the proximal apical half. Hind tibia with 1 submedian anterodorsal and 1 apical seta shorter than submedian; 1 long submedian posterodorsal seta; 2 submedian and 1 apical anteroventral setae; 1 long pre-apical dorsal seta.

Abdomen. Tergite 1+2 with a lateral bristles tuft, tergite 5 with a row of discal bristles. Sternite 5 large, with a deep median concavity (Fig. 4).
Terminalia. Cercal plate short, surstily fine and long, baciliform process "c" shaped. (Figs 5-6). Aedeagus as in Fig. 7. Female differs from male as follows.

Length: 6,1 $\mathrm{mm}$; wing: 5,2 $\mathrm{mm}$.

Eyes bare, facets of same size; dicoptic. About 10 pairs of long frontal setae. Mid femur only with a row of long posterior setae in the apex. Mid tibia straigth, with no concavities. Hind femur only with submedian and pre-apical anteroventral setae. Hind tibia only with 1 submedian anterodorsal seta; 1 submedian and 1 pre-apical dorsal setae. Abdomen. Tergite 5 without the pairs of apical setae.

Ovipositor and spermathecae as in figures 8 and 9 , respectively.

Discussion. F. caramaschi belongs to the obscurinervis group and approaches $F$. itatiaiensis Albuquerque, 1956 in ALBUQUERQUe et al. (1981) key, from which it can be easily segregated by the number of frontal setae, maculation of the wing and the quetotaxy of hind leg.

Material examined. Holotype male: Brazil, Amazonas: Município de Barcelos (Pico Tamacuari, $2700 \mathrm{~m}$ NW da Missão Marari, $1^{\circ} 12^{\prime} 26,4^{\prime \prime} \mathrm{N} ; 64^{\circ} 47^{\prime} 18,1^{\prime \prime}, 340 \mathrm{~m}$ de altitude, 29.IV-10.V. 2004, U. Caramaschi leg. Three paratypes male and one female: same labels as holotype (MNRJ).

\section{ACKNOWLEDGMENTS}

To Dr. Ulisses Caramaschi (Museu Nacional) for the opportunity to study this material and for the description of the area; to $\mathrm{CNPq}$ for the research grant to MSC (process number 300386/80-0).

\section{REFERENCES}

Albuquerque, D. de O.; D. Pamplona \& C.J.B. de Carvalho. 1981. Contribuição ao conhecimento dos Fannia R.-D., 1830 da região neotropical (Diptera, Fanniidae). Archivos do Museu Nacional, Rio de Janeiro, 56: 9-34.

Carvalho, C.J.B. de; A.C. Pont; M.S. Couri \& D. Pamplona. 2003. A Catalogue of the Fanniidae (Diptera) of the Neotropical Region. Zootaxa, Auckland, 219: 1-32.

Couri, M.S. (in press). A new species of Fannia RobineauDesvoidy (Diptera, Fanniidae). Brazilian Journal of Biology, Rio de Janeiro.

Myers, C.W. \& M.A. Donnelly. 1997. A Tepui herpetofauna on a granitic mountain (Tamacuari) in the borderland between Venezuela and Brazil: report from the Phipps Tapirapecó Expedition. American Museum Novitates, New York, (3213): 1-71.

Received in 29.X.2004; accepted in 04.VIII.2005. 